\title{
Effect of an educational program for Nurses working in Maternal and Child Health Care Centers about Health Care Waste Management
}

\author{
Samia Farouk Mahmoud ${ }^{(1)}$, Seham, I.,Abdelrhman Alhanafy ${ }^{(2)}$,and Hanan Elsayed Awad Negm ${ }^{(3)}$ \\ (1) \&(2) Assistant Professor of Community Health Nursing department, Faculty of Nursing, Zagazig \\ University \\ (3) Lecturer of Community Health Nursing, Faculty of Nursing, Port- Said University
}

\begin{abstract}
:
Background: The problem of how to properly dispose of healthcare waste has been a serious challenge. The aim of this research was to evaluate the effect of an educational program for nurses working in Maternal and Child Health Care Centers about health care waste management. Design: A quasi-experimental design was used. Settings: This research took place at 16 Maternal and Child Health Care Centers in Zagazig City, Sharikia Governorate, Egypt, which were chosen randomly from 34 Maternal and Child Health Care Centers and all nurses in MCH centers, was recruited for this study. Sample: A simple random sample of 99 nurses from the Maternal and Child Health Care Centers. Tools: Two tools were used for data collection. Tool I: Data were collected about nurses' sociodemographic characteristics and their knowledge about waste management before and after the program using a selfadministered knowledge questionnaire. Tool II: To evaluate nurses' waste management practices using an observation checklist. Results: The total good knowledge level in pre-intervention was $57.6 \%$, which improved to $94.9 \%$ after one month of intervention. Furthermore, the total score of nurses' practices increased from $28.3 \%$ at preintervention to $71.7 \%$ after one-month post-intervention. Conclusion: It was concluded that the educational program effectively improved nurses' knowledge and practices, while the practice concerning controlling health care waste is still inadequate. There was a highly statistically significant positive linear correlation between the nurses' knowledge and reported practices regarding the management of healthcare waste before and after applying the educational program $\mathrm{p}<0.01$. Recommendations: Pre-employment health education programs should be provided for Egyptian nurses on biomedical waste management with orientation to organization, and they must be checked regularly.
\end{abstract}

Key Words: Waste, Management, Nurses, Intervention, MCH Center.

Introduction:

Biomedical waste management has recently emerged as an issue of major concern to hospitals, primary healthcare centers, nursing home authorities, and the environment (Hakim et al., 2017). Medical facility advancements and the introduction of more sophisticated equipment have resulted in a rise in waste generated per customer in healthcare facilities globally (Haque et al., 2018). The WHO estimates that highincome nations produce up to $0.5 \mathrm{~kg}$ of hazardous waste per hospital bed each day on average. Although low-income nations generate just $0.2 \mathrm{~kg}$ of hazardous trash per hospital bed per day, healthcare waste is often not sorted into hazardous and non-hazardous wastes, implying that the true amount of hazardous waste is considerably greater (WHO, 2014).

WHO (2014) divided medical waste into eight groups: general waste, pathological, radioactive, chemical, and infectious to potentially infectious waste, sharps, pharmaceuticals, and pressurized containers. In the same way, Elsayed and Rashad (2014) classified it into solid or liquid wastes. Sharps, wasted blood, undesired microbiological cultures, and stocks, discarded gloves, recognizable body parts, worn bandages and dressings, and other medical items that have come into touch with blood and bodily fluids are all examples of infectious waste.

Egypt, like several other developing countries, is attempting to improve its hospital waste management procedures. Although Environmental Law No. 4 of 1994 was enacted to standardize the execution of integrated hospital waste management, authorities have been unable to establish effective systems for waste segregation, collection, transport, or treatment owing to lax legislative enforcement. Due to established rules and procedures, healthcare professionals in Egypt often are ignorant of this law. 
Incineration or autoclaving are the most often used ultimate waste disposal techniques. Incineration is used in most ordinary hospitals in Egypt, whereas autoclaving is used in most of the teaching and university hospitals (WHO, 2014).

Inadequate healthcare waste management pollutes the environment, and infectious waste may result in the spread of more than 30 major diseases, including typhoid, hepatitis B, hepatitis C, HIV, Escherichia coli, Staphylococcus aureus, and Pseudomonas aeruginosa (Debere et al., 2014). When healthcare waste is disposed of in landfills or buried, it is possible for groundwater to get contaminated, leading in the spread of E. coli. Pathogens found in manure may also penetrate and stay in the air in the form of spores or pathogens for an extended length of time. As a result, healthcare facilities should improve their waste segregation, sorting, and resource recycling and recovery practices. Additionally, effective waste treatment techniques reduce not only the weight and amount of trash, but also its infectivity and organic components (Padmanabhan \& Barik, 2019).

Poor healthcare waste management (HCWM) practices may result in clients, staff, waste handlers and the community being exposed to the unnecessary health risks of the waste. Healthcare waste is usually discarded with residential waste in developing nations, where HCWM has not gained significant traction (Padmanabhan \& Barik, 2019). In developing nations, improper HCWM practices are concerning due to a lack of resources to manage wastes (Ferronato et al., 2019).

The nursing profession acknowledges the critical role of nature in global health and the real danger presented by medical waste globally. The International Council of Nurses (ICN) believes that all nurses have a responsibility to minimize/eliminate the negative environmental effect of medical waste. As representing organizations of nurses and nursing, the ICN and national nurses associations (NNAs) are responsible for clinical and policy choices regarding medical waste. Nurses who operate in clinical settings generate medical waste and are responsible for its disposal. Nurses in management positions develop rules for the procurement of products, as well as the production and disposal of medical waste (Maroufi et al., 2014).

\section{Significance of the Study}

The current trend of using disposables, and the expansion of healthcare institutions, has resulted in an exceptional load of health-care-related trash, therefore un-controlled biomedical waste disposal is developing as a severe hazard to human health and safety (Mostafa et al., 2014). Each day, Egypt generates an estimated 24,600 tons of hazardous or infectious waste from all health care facilities (excluding military hospitals). To safeguard the environment, the public, and workers, mainly nurses and lab technicians who are at contact with biomedical waste must be appropriately managed and disposed of (Sağlık, et al., 2014). Furthermore, nearly threequarters of them lacked waste management training (Elsayed \& Rashad, 2014). This study established on nurses assumed that it should develop nurses' knowledge and practices concerning health care waste management.

\section{Aim of the Study:}

The aim of the study was to evaluate the effect of an educational program for nurses working in Maternal and Child Health Care Centers, about health care waste management, at Zagazig City, through:

1. Assessing nurses' knowledge of health-care waste management before and after the intervention program is applied.

2. Evaluating nurses' practices before and after the intervention program is applied.

3. Plan, implement, and evaluate the effect of nursing intervention on improving nurses' performance toward health-care waste management.

\section{Research Hypothesis:}

Nurses' knowledge and practices of bio-medical waste management in $\mathrm{MCH}$ centers will be improved through application of an educational program.

\section{Subjects and Methods}

\section{Research Design}

A quasi-experimental design was used in this study.

Research settings:

The current research was carried out on 16 maternal and child healthcare centers from 34 maternal and child health-care centers at Zagazig City, in Sharkia Governorate. These centers were randomly selected and named maternal and child health Centers in Shaybah Al-Nakariah, Shabanat, Bahnbay, AlNakhas, Shambara Al-Maimuna, Umm Ramad, Taybeh, Umm Al-Zain, Bani Amer, Zinkolon, Al- 
Aslouji, Kafr Abaza, Safita, Kafr Abdel Aziz, Kafr AlHamam, and maternal and child health center in Kafr Musa Omran.

\section{Sample size calculation and technique}

Zagazig is a city in Lower Egypt. Situated in the eastern part of the Nile delta, it is the capital of the governorate of Sharqia. Based on data from literature (Elsayed \& Rashad, 2014), considering level of significance $=5 \%$, Power $=80 \%$. Formula of calculating sample size is as follows:

$\mathrm{n}=\left[2\left(Z_{\alpha / 2}+Z_{\beta}\right)^{2} \times p(1-p)\right] /(p 1-p 2)^{2}$

where $n=$ required sample size, $\mathrm{p}=$ Pooled proportion, p1 and p 2 are the event proportion difference between two groups, $Z_{\alpha / 2}$ equals to 1.96 for $5 \%$ level of significance, and $Z_{\beta}$ equals to 0.84 for $80 \%$ power of the study. Accordingly, $n=\left[2(1.96+0.84)^{2} \times 0.984(1-\right.$ $0.984)] /(0.05)^{2}=98.7$. According to the previous equation, the estimated sample size was 99 .

Researchers explored the knowledge and practices of health-care waste management among nurses from 16 Maternal and Child Health Care Centers in Zagazig City (randomly chosen through sealed envelope method); Based on the personnel numbers in each center, the sample size was distributed among the $\mathrm{MCH}$ Centers as follows: maternal and child health Centers in Shaybah Al-Nakariah (10 nurses), Shabanat (7 nurses), Bahnbay (6 nurses), AlNakhas (7 nurses), Shambara Al-Maimuna (5 nurses), Umm Ramad (8 nurses), Taybeh (6 nurses), Umm AlZain (7 nurses), Bani Amer (6 nurses), Zinkolon (6 nurses), Al-Aslouji (7 nurses), Kafr Abaza (5 nurses), Safita (6 nurses), Kafr Abdel Aziz (4 nurses), Kafr AlHamam (5 nurses), and maternal and child health center in Kafr Musa Omran (4 nurses).

\section{Tools of data collection:}

Two tools were applied for data collection:

Tool I: A questionnaire that was self-administered: It was created by the researchers after, reviewing relevant literature, facilitated by Elsayed and Rashad (2014). It consisted of two parts of closed-ended questions that were used to evaluate the following:

- Part I: The socio-demographic characteristics of the nurses including, nurse's age, gender, residence, educational level, profession, marital status, years of experience, income, attending training courses, vaccination against virus $B$, history of needle stick injuries, and history of infections with virus $B$ and $C$.

- Part II: A self-administered questionnaire was established to assess nurse's knowledge about health care waste management before and after program application as; definition of bio-medical waste, types, sources of bio-medical waste, responsibilities, hazards, technology methods for handling of waste management, color coded of bio-medical waste and segregation of bio-medical waste, and correction procedures regarding needle stick injuries.

\section{Scoring system}

The questionnaire sheet's scoring method was as follows: Accurate and complete responses (2points), correct incomplete responses received (one point), and don't know or incorrect responses (zero point). The overall score for all knowledge-related questions was 32. The researchers translated the overall knowledge levels into 3 categories: poor knowledge $(<50 \%$ of the maximum score), fair knowledge $(50-65 \%$ of the maximum score) and good knowledge $(>65 \%$ of the maximum score).

Tool II: Observational checklist of the nurses to assess nurse's practices toward bio-medical waste management. It was adapted from Elsayed and Rashad (2014), such as segregation of waste, dispose of sharps in puncture-resistant containers, closing the container, use of personal protective devices, hand wash and use alcohol-based antiseptic hand rub.

\section{Scoring system:}

The observation checklist score method was as follows: Each step that was completed properly, was awarded (one point), and each step that was not completed (zero points). The scores of the individual items were summed up to calculate the total practice score. The researchers translated the total score to a percentile ranking. For each category, the total practice score was dichotomized as follows: $\geq 60.0 \%$ deemed adequate, and $<60.0 \%$ deemed inadequate.

\section{Fieldwork:}

Upon securing all official permissions, the process of data collection started. The researchers attended at the Maternal and Child Health Care Centers at Zagazig City 2 days weekly for each $\mathrm{MCH}$ center, at the morning shift from 9.00 a.m. to 1.00 p.m. Data collection extended over a period of six months from the $1^{\text {st }}$ of January 2021 to the end of June 2021 for 
pretest, educational program sessions' implementation, and posttest. The researchers started by introducing themselves to nurses and briefly discussed the objectives of the research to the managers of the maternal and child health centers. Nurses were interviewed individually. Time consumed for each interview lasted 20-30 minutes.

The framework of the study was carried out through the following:

Administrative and ethical considerations:

After explaining the study's purpose, an official letter from the Faculty of Nursing was submitted to the competent authority of Zagazig University's administrative building to obtain their authorization for data collection. Each nurse user gave informed oral permission; all ethical issues were taken into consideration during all phases of the study.

\section{Tools development:}

The researchers made some changes to the instruments after reviewing recent related literature. Tools Validity:

A jury of three experts, in the Community Health Nursing department, from the Faculty of Nursing and Faculty of Medicine at Zagazig University, assessed both of the study's tools for content validity, and the proposed some changes that were made.

\section{Tools Reliability:}

Cronbach's Alpha was used to conduct the reliability test, and the tools appeared to be reliable, where, the self-administered knowledge of waste management scale ( $\mathrm{r}=0.86)$, and nurses' waste management practices observational checklist $(\mathrm{r}=$ 0.95), which indicate high internal consistency.

\section{Pilot study:}

Before conducting the main study, a pilot study was carried out on 10 nurses (10\% of the sample), to verify the tools'. The piloted nurses were later excluded from the main study sample, and the final form of the tools was them obtained and the time needed for completing each tool was estimated.

\section{Data collection process:}

The overall data collection process took about six months (beginning of January 2021 to end of June 2021).

\section{Program:}

The educational intervention for nurses about biomedical waste management was devised and implemented in the following four stages:

I. Assessment phase: Assessment of nurses' knowledge and health care practices regarding health care waste management before the implementation of the educational program was done.
II. Planning phase: Based on the findings of the assessment phase; goals, priorities, and expected outcomes were formulated to meet nurses' needs of knowledge and practices to be able for providing knowledge and practices toward bio-medical waste management.

General objective: The general objective of the nurses 'sessions was to raise the nurses knowledge, and practices working in Maternal and Child Health Centers about bio-medical waste management.

Specific objectives: By the end of sessions, nurses would be able to:

- Identify the definition, and types of bio-medical waste management.

- Discuss the sources of bio-medical waste.

- Know the responsible of the bio-medical waste management.

- Recognize the hazards of the bio-medical waste management.

- Describe the technology methods for handling of waste management.

- Explain the color coded of bio-medical waste.

- Describe the segregation of bio-medical waste.

- Apply the correction procedures regarding needle stick injuries.

III. Implementation phase: Preparation of suitable media such as booklet, posters, and brochures for teaching the nurses was done. Implementation of the educational program was carried out at the previously mentioned settings. The educational program consisted of 3 sessions once every week and every session lasted for 20- 30 minutes. These sessions were performed individually for each $\mathrm{MCH}$ centers and a copy of the intervention program's contents was distributed for each nurse. The first session addressed the definition of biomedical waste, the different kinds of biomedical waste, the sources of biomedical waste, and the risks associated with biomedical waste. The second session dealt with the technology methods for handling of waste management in hospitals, and color coded of bio-medical waste and segregation of bio medical waste. The third session was concerned with hand washing, personal protective devices like gloves, mask, and application of healthcare waste management.

\section{Evaluation phase:}

After one month of intervention, and after implementation of sessions, the nursing educational intervention was assessed using the same pretest tools to compare changes in nurses' knowledge and practices about health care bio-medical waste management.

Statistical Analysis

All statistical analyses were performed using SPSS for windows version 20.0 the Statistical Package for Social 
Sciences (SPSS, Chicago, IL). All continuous data were normally distributed and were expressed in mean \pm standard deviation (SD). Categorical data were expressed in number and percentage. Chi-square test was used for comparison of variables with categorical data. Correlation co-efficient test was used to test for correlations between two variables with continuous data. The reliability (internal consistency) test for the questionnaires used in the study was calculate. Statistical significance was set at $\mathrm{p}<0.05$.

\section{Results:}

Table (1) shows the socio-demographic characteristics of studied nurses. It displays that the mean age of nurses was $42.2 \pm 9.9$ years. According to their education, $62.6 \%$ of the nurses had diploma of nursing. Regarding the years of experience, $33.3 \%$ of the nurses had an experience ranged from 21 to 30 years. while, $42.4 \%$ of nurses stated that they had not attended any waste management training, and $68.7 \%$ of them got immunization against virus-B. Additionally, $18.2 \%$ of nurses have history of injury needle. However, only $2.0 \%$ and $3.0 \%$ have history of infection with virus $\mathrm{C}$ and virus $\mathrm{B}$ respectively.

Table (2) demonstrates the degree of knowledge about health care waste management among the nurses examined during the program. As shown in the table, in all knowledge items, nurses had lower knowledge level pre-intervention which was significantly improved post-intervention. As seen, $90.91 \%, 93.94 \%, 98.99 \%, 100.0 \%, 93.94 \%, 96.97 \%$, $100.0 \%$, and $87.88 \%$ of the sample responded correctly and completely posttest concerning the definition, types, sources, the responsibility of management of bio medical waste and hazards. In addition to technology methods for handling of wastes, color coded of biomedical waste, and corrections procedures to be followed wherever exposure to a needle prick respectively. However, at pretest these were $28.28 \%$, $44.44 \%, 47.47 \%, 93.94 \%, 27.27 \%, 49.49 \%, 87.88 \%$, $32.32 \%$ respectively. These differences were statistically significant.

Figure (1) illustrates total knowledge level between pre and post interventions and shows that $57.6 \%$ of nurses have good knowledge pre intervention which improved to $94.9 \%$ post- intervention.

Table (3) demonstrates the practices regarding medical waste as observed among studied nurses throughout the program. According to the table, low levels of practice scores were done in relation to all items of waste management of healthcare pre implementation of the program. It can be noticed that the nurses who participated in the study had the lowest level of practice $(54.5 \%)$ at the pre-program phase in relation to hand washing. However, a statistically significant increase was detected in the level of practice in the post test $(87.9 \%)$. As well, $67.7 \%$ used personal protective devices like gloves, mask while handling the waste in posttest compared to $(48.5 \%)$ of nurses in pretest.

Figure (2) illustrates that the total score of nurses' practices increased from $28.3 \%$ at preintervention to $71.7 \%$ at post-intervention.

Table (4) reveals highly statistically significant associations between socio-demographic characteristics (education, profession, years of experience years, training about medical waste, taking vaccine for virus $B$, history of injury needle, history of infection with virus $C, \&$ history of infection with virus B) and knowledge level post-intervention at p-value $<0.001$.

Table (5) shows statistically significant differences between all socio-demographic characteristics and practices post-intervention at pvalue $<0.01$, except for age, gender, residence, and income.

Table (6) displays association between total knowledge score and practice pre intervention. It indicates highly statistically positive association between total knowledge score and practices score with most of nurses $(33,68.8 \%)$ with good knowledge level had a statistically practice level ( $\mathrm{X}^{2} 7.337$ at $\left.\mathrm{p} 0.025\right)$.

Table (7) presents association between total the knowledge score and total practices postintervention. It reveals statistically positive associations between total knowledge score and practices post-intervention $(\mathrm{X} 2=6.944$ at $\mathrm{p}=0.008)$.

Figure (3) illustrates that the total knowledge score is increasing correlated with the total practice score post-intervention. 
Table 1. Distribution of the Socio-demographic Characteristics and Past Medical History of Nurses at Maternal and Child Health Centers $(n=99)$

\begin{tabular}{|c|c|c|c|}
\hline & Socio-demographic Characteristics & $\mathbf{N}$ & $\%$ \\
\hline \multirow[t]{5}{*}{ Age (in years) } & $20-30$ & 19 & 19.2 \\
\hline & $31-40$ & 18 & 18.2 \\
\hline & $41-50$ & 39 & 39.4 \\
\hline & More than 50 & 23 & 23.2 \\
\hline & Mean \pm SD & $42.2 \pm 9.9$ & \\
\hline \multirow[t]{2}{*}{ Gender } & Male & 6 & 6.1 \\
\hline & Female & 93 & 93.9 \\
\hline \multirow[t]{2}{*}{ Residence } & Rural & 53 & 53.5 \\
\hline & Urban & 46 & 46.5 \\
\hline \multirow[t]{3}{*}{ Education } & Bachelor nursing & 11 & 11.1 \\
\hline & Institute nursing & 26 & 26.3 \\
\hline & Diploma nursing & 62 & 62.6 \\
\hline \multirow[t]{3}{*}{ Profession } & Supervisors & 11 & 11.1 \\
\hline & Lab scientist & 16 & 16.2 \\
\hline & Nurse & 72 & 72.7 \\
\hline \multirow[t]{4}{*}{ Marital status } & Single & 4 & 4.0 \\
\hline & Married & 88 & 88.9 \\
\hline & Divorced & 4 & 4.0 \\
\hline & Widowed & 3 & 3.0 \\
\hline \multirow[t]{7}{*}{ Experience (in years) } & $1-3$ & 6 & 6.1 \\
\hline & $4-7$ & 4 & 4.0 \\
\hline & $8-10$ & 8 & 8.1 \\
\hline & $11-20$ & 18 & 18.2 \\
\hline & $21-30$ & 33 & 33.3 \\
\hline & $31-40$ & 27 & 27.3 \\
\hline & $>40$ & 3 & 3.0 \\
\hline \multirow[t]{2}{*}{ Income } & Insufficient & 46 & 46.5 \\
\hline & Sufficient & 53 & 53.5 \\
\hline \multirow[t]{2}{*}{ Training about medical waste } & No & 42 & 42.4 \\
\hline & Yes & 57 & 57.6 \\
\hline \multirow[t]{2}{*}{ Taking vaccine for virus $B$} & No & 31 & 31.3 \\
\hline & Yes & 68 & 68.7 \\
\hline \multirow[t]{2}{*}{ History of needle injury } & No & 81 & 81.8 \\
\hline & Yes & 18 & 18.2 \\
\hline \multirow[t]{2}{*}{ History of infection with virus $C$} & No & 97 & 98.0 \\
\hline & Yes & 2 & 2.0 \\
\hline \multirow[t]{2}{*}{ History of infection with virus B } & No & 96 & 97.0 \\
\hline & Yes & 3 & 3.0 \\
\hline
\end{tabular}


Table 2. Distribution of Knowledge about Medical Waste of Nurses at Maternal and Child Health Centers (n=99)

\begin{tabular}{|c|c|c|c|c|c|c|}
\hline \multirow{3}{*}{ Knowledge } & \multirow{2}{*}{\multicolumn{2}{|c|}{\begin{tabular}{|l} 
Pre \\
Complete
\end{tabular}}} & \multicolumn{2}{|c|}{ Post (after one month) } & \multirow{2}{*}{\multicolumn{2}{|c|}{ Chi-Square }} \\
\hline & & & \multicolumn{2}{|c|}{ Complete } & & \\
\hline & $\mathbf{N}$ & $\%$ & $\mathbf{N}$ & $\%$ & $\mathrm{X}^{2}$ & $\mathbf{P}$ \\
\hline Definition & 28 & 28.3 & 90 & 90.9 & 80.7105 & $<0.001^{*}$ \\
\hline Types & 44 & 44.4 & 93 & 93.9 & 57.8744 & $<0.001^{*}$ \\
\hline Sources & 47 & 47.5 & 98 & 99.0 & 67.0522 & $<0.001 *$ \\
\hline Responsibility & 93 & 93.9 & 99 & 100.0 & 6.1875 & $0.013^{*}$ \\
\hline Hazards & 27 & 27.3 & 93 & 93.9 & 92.387 & $<0.001^{*}$ \\
\hline Technology methods & 49 & 49.5 & 96 & 97.0 & 57.2631 & $<0.001^{*}$ \\
\hline Color & 87 & 87.9 & 99 & 100.0 & 12.7742 & $<0.001^{*}$ \\
\hline Correction procedures & 32 & 32.3 & 87 & 87.9 & 66.3512 & $<0.001^{*}$ \\
\hline \multirow[b]{2}{*}{100} & & Pre-Int & ר & rention & \multirow{3}{*}{94.9} & \\
\hline & & & 308, & & & \\
\hline 90 & & & & & & \\
\hline \multirow{2}{*}{\multicolumn{7}{|c|}{80}} \\
\hline \multicolumn{5}{|l|}{70} & & \\
\hline \multicolumn{7}{|l|}{60} \\
\hline \multicolumn{7}{|l|}{ ஃ 50} \\
\hline \multicolumn{7}{|l|}{40} \\
\hline \multicolumn{7}{|l|}{30} \\
\hline \multicolumn{7}{|l|}{20} \\
\hline 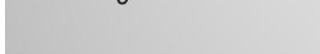 & & & & & Go & \\
\hline
\end{tabular}

Figure 1. Comparison of total knowledge levels between pre and post intervention

Table 3. Number and Percentage Distribution of Practice Regarding Medical Waste (n=99)

\begin{tabular}{|c|c|c|c|c|c|c|}
\hline \multirow[b]{3}{*}{ Practice } & \multicolumn{2}{|l|}{ Pre } & \multicolumn{2}{|c|}{ Post (after one month) } & & \\
\hline & Don & & Dol & & \multicolumn{2}{|c|}{ Chi-Square } \\
\hline & n & $\%$ & $\mathbf{n}$ & $\%$ & $\mathbf{X}^{2}$ & $\mathbf{P}$ \\
\hline $\begin{array}{l}\text { Separation of infectious and non- } \\
\text { infectious waste at the waste } \\
\text { generation site. }\end{array}$ & 71 & 71.7 & 78 & 78.8 & 1.328 & 0.249 \\
\hline $\begin{array}{l}\text { Dispose of sharps in puncture- } \\
\text { resistant containers }\end{array}$ & 59 & 59.6 & 80 & 80.8 & 10.647 & $<0.001 *$ \\
\hline $\begin{array}{l}\text { Close the container shortly after } \\
\text { placing the waste }\end{array}$ & 56 & 56.6 & 72 & 72.7 & 5.657 & $0.017^{*}$ \\
\hline $\begin{array}{l}\text { Use of personal protective equipment } \\
\text { such as gloves and masks while } \\
\text { handling waste. }\end{array}$ & 48 & 48.5 & 67 & 67.7 & 7.488 & $0.006^{*}$ \\
\hline Hand washing & 54 & 54.5 & 63 & 87.9 & 66.3512 & $<0.001 *$ \\
\hline $\begin{array}{l}\text { Use an alcohol-based hand sanitizer } \\
\text { after removing gloves when handling } \\
\text { waste }\end{array}$ & 66 & 66.7 & 81 & 81.8 & 5.942 & $0.015^{*}$ \\
\hline
\end{tabular}




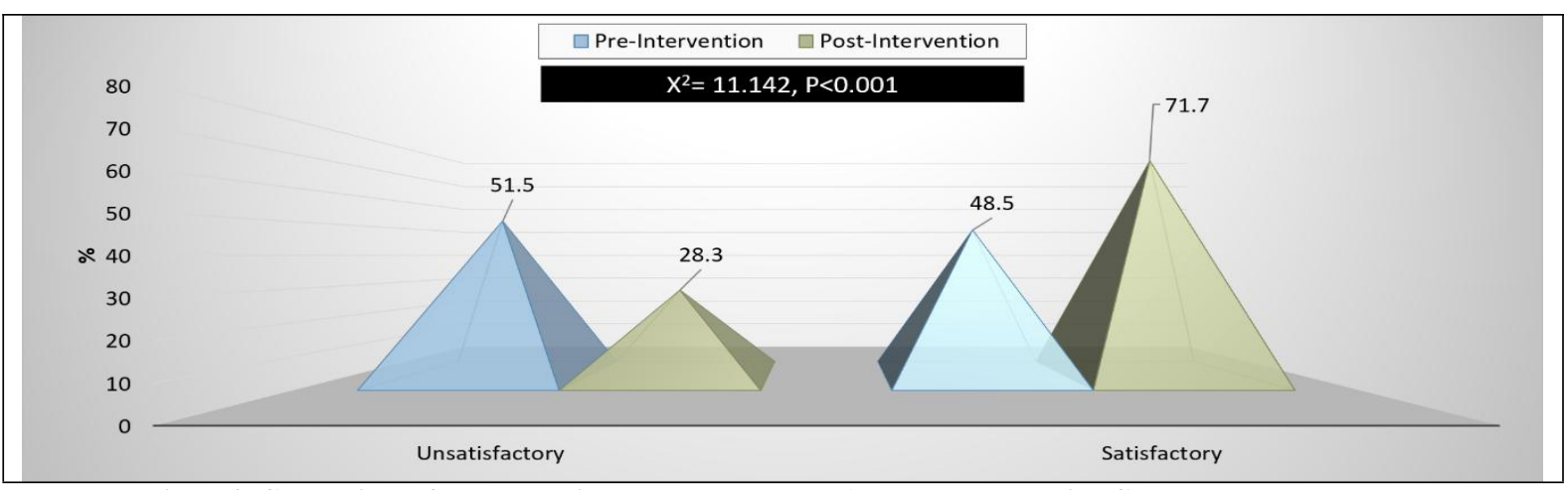

Figure 2. Comparison of Total Practice Level Between Pre And Post Intervention Change

Table 4. Associations between the Socio-demographic Characteristics and Knowledge post-intervention

\begin{tabular}{|c|c|c|c|c|c|c|}
\hline \multirow[t]{2}{*}{ Variable } & \multicolumn{2}{|c|}{ Fair $(n=5)$} & \multicolumn{2}{|c|}{$\operatorname{Good}(n=94)$} & \multicolumn{2}{|c|}{ Chi-Square } \\
\hline & $\mathrm{N}$ & $\%$ & $\mathrm{~N}$ & $\%$ & $\mathrm{X}^{2}$ & $\mathrm{P}$ \\
\hline \multicolumn{7}{|l|}{ Age (in years) } \\
\hline $20-<31$ & 1 & 20.0 & 18 & 19.1 & & \\
\hline $31-<41$ & 0 & 0.0 & 18 & 19.1 & & \\
\hline $41-50$ & 1 & 20.0 & 38 & 40.4 & & \\
\hline$>50$ & 3 & 60.0 & 20 & 21.3 & 4.526 & 0.210 \\
\hline \multicolumn{7}{|l|}{ Gender } \\
\hline Male & 0 & 0.0 & 6 & 6.4 & & \\
\hline Female & 5 & 100.0 & 88 & 93.6 & 0.340 & 0.560 \\
\hline \multicolumn{7}{|l|}{ Residence } \\
\hline Rural & 4 & 80.0 & 49 & 52.1 & & \\
\hline Urban & 1 & 20.0 & 45 & 47.9 & 1.483 & 0.223 \\
\hline \multicolumn{7}{|l|}{ Education } \\
\hline Bachelor nursing & 0 & 0.0 & 11 & 11.7 & & \\
\hline Institute nursing & 4 & 80.0 & 22 & 23.4 & & \\
\hline Diploma nursing & 1 & 20.0 & 61 & 64.9 & 7.903 & $0.019 *$ \\
\hline \multicolumn{7}{|l|}{ Profession } \\
\hline Supervisors & 0 & 0.0 & 11 & 11.7 & & \\
\hline Lab scientist & 3 & 60.0 & 13 & 13.8 & & \\
\hline Nurse & 2 & 40.0 & 70 & 74.5 & 7.622 & $0.022 *$ \\
\hline \multicolumn{7}{|l|}{ Marital status } \\
\hline Single & 0 & 0.0 & 4 & 4.3 & & \\
\hline Married & 5 & 100.0 & 83 & 88.3 & & \\
\hline Divorced & 0 & 0.0 & 4 & 4.3 & & \\
\hline Widowed & 0 & 0.0 & 3 & 3.2 & 0.658 & 0.883 \\
\hline \multicolumn{7}{|c|}{ Experience (in years) } \\
\hline$\leq 10$ & 0 & 0.0 & 18 & 19.1 & & \\
\hline $11-20$ & 0 & 0.0 & 18 & 19.1 & & \\
\hline $21-30$ & 5 & 100.0 & 28 & 29.8 & & \\
\hline $31-40$ & 0 & 0.0 & 27 & 28.7 & & \\
\hline$>40$ & 0 & 0.0 & 3 & 3.2 & 10.532 & $0.032 *$ \\
\hline \multicolumn{7}{|l|}{ Income } \\
\hline Insufficient & 4 & 80.0 & 42 & 44.7 & & \\
\hline Sufficient & 1 & 20.0 & 52 & 55.3 & 2.381 & 0.123 \\
\hline \multicolumn{7}{|c|}{ Training about medical waste } \\
\hline No & 5 & 100.0 & 37 & 39.4 & & \\
\hline Yes & 0 & 0.0 & 57 & 60.6 & 7.147 & $0.007 *$ \\
\hline \multicolumn{7}{|c|}{ Vaccination against virus $B$} \\
\hline No & 4 & 80.0 & 27 & 28.7 & & \\
\hline Yes & 1 & 20.0 & 67 & 71.3 & 5.804 & $0.016^{*}$ \\
\hline \multicolumn{7}{|c|}{ History of needle injury } \\
\hline $\mathrm{No}$ & 2 & 40.0 & 79 & 84.0 & & \\
\hline Yes & 3 & 60.0 & 15 & 16.0 & 6.190 & $0.013^{*}$ \\
\hline \multicolumn{7}{|c|}{ History of virus $C$ infection } \\
\hline No & 4 & 80.0 & 93 & 98.9 & & \\
\hline Yes & 1 & 20.0 & 1 & 1.1 & 8.600 & $0.003 *$ \\
\hline \multicolumn{7}{|c|}{ History of virus $B$ infection } \\
\hline $\mathrm{No}$ & 4 & 80.0 & 92 & 97.9 & & \\
\hline Yes & 1 & 20.0 & 2 & 2.1 & 5.161 & $0.023 *$ \\
\hline
\end{tabular}


Table 5. Associations between the Socio-demographic Characteristics and Practices postintervention

\begin{tabular}{|c|c|c|c|c|c|c|}
\hline \multirow[t]{2}{*}{ Variables } & \multicolumn{2}{|c|}{$\begin{array}{l}\text { Unsatisfactory }(n=28) \text { or } \\
\text { not done }\end{array}$} & \multicolumn{2}{|c|}{$\begin{array}{l}\text { Satisfactory }(n=71) \text { or } \\
\text { done }\end{array}$} & \multicolumn{2}{|c|}{ Chi-Square } \\
\hline & $\mathrm{N}$ & $\%$ & $\mathrm{~N}$ & $\%$ & $\mathrm{X}^{2}$ & $P$ \\
\hline \multicolumn{7}{|l|}{ Age } \\
\hline $20-<31$ & 4 & 14.3 & 15 & 21.1 & & \\
\hline $31-<41$ & 5 & 17.9 & 13 & 18.3 & & \\
\hline $41-50$ & 10 & 35.7 & 29 & 40.8 & & \\
\hline$>\mathbf{5 0}$ & 9 & 32.1 & 14 & 19.7 & 1.960 & 0.581 \\
\hline \multicolumn{7}{|l|}{ Gender } \\
\hline Male & 3 & 10.7 & 3 & 4.2 & & \\
\hline Female & 25 & 89.3 & 68 & 95.8 & 1.485 & 0.223 \\
\hline \multicolumn{7}{|l|}{ Residence } \\
\hline Rural & 19 & 67.9 & 34 & 47.9 & & \\
\hline Urban & 9 & 32.1 & 37 & 52.1 & 3.219 & 0.073 \\
\hline \multicolumn{7}{|l|}{ Education } \\
\hline Bachelor nursing & 4 & 14.3 & 7 & 9.9 & & \\
\hline Institute nursing & 12 & 42.9 & 14 & 19.7 & & \\
\hline Diploma nursing & 12 & 42.9 & 50 & 70.4 & 6.884 & $0.032 *$ \\
\hline \multicolumn{7}{|l|}{ Profession } \\
\hline Supervisor & 4 & 14.3 & 7 & 9.9 & & \\
\hline Lab scientist & 9 & 32.1 & 7 & 9.9 & & \\
\hline Nurse & 15 & 53.6 & 57 & 80.3 & 8.494 & $0.014 *$ \\
\hline \multicolumn{7}{|l|}{ Marital status } \\
\hline Single & 0 & 0.0 & 4 & 5.6 & & \\
\hline Married & 24 & 85.7 & 64 & 90.1 & & \\
\hline Divorced & 1 & 3.6 & 3 & 4.2 & & \\
\hline Widowed & 3 & 10.7 & 0 & 0.0 & 9.250 & $0.026^{*}$ \\
\hline \multicolumn{7}{|c|}{ Experience (in years) } \\
\hline$\leq \mathbf{1 0}$ & 3 & 10.7 & 15 & 21.1 & & \\
\hline $11-20$ & 6 & 21.4 & 12 & 16.9 & & \\
\hline $21-30$ & 15 & 53.6 & 18 & 25.4 & & \\
\hline $31-40$ & 3 & 10.7 & 24 & 33.8 & & \\
\hline$>40$ & 1 & 3.6 & 2 & 2.8 & 10.184 & $0.037 *$ \\
\hline \multicolumn{7}{|l|}{ Income } \\
\hline Insufficient & 12 & 42.9 & 34 & 47.9 & & \\
\hline Sufficient & 16 & 57.1 & 37 & 52.1 & 0.204 & 0.651 \\
\hline \multicolumn{7}{|c|}{ Training about medical waste } \\
\hline No & 17 & 60.7 & 25 & 35.2 & & \\
\hline Yes & 11 & 39.3 & 46 & 64.8 & 5.347 & $0.021 *$ \\
\hline \multicolumn{7}{|c|}{ Taking vaccine for virus $B$} \\
\hline No & 13 & 46.4 & 18 & 25.4 & & \\
\hline Yes & 15 & 53.6 & 53 & 74.6 & 4.147 & $0.042 *$ \\
\hline \multicolumn{7}{|c|}{ History needle of injury } \\
\hline No & 19 & 67.9 & 62 & 87.3 & & \\
\hline Yes & 9 & 32.1 & 9 & 12.7 & 5.115 & $0.024 *$ \\
\hline \multicolumn{7}{|c|}{ History of virus $C$ infection } \\
\hline No & 26 & 92.9 & 71 & 100.0 & & \\
\hline Yes & 2 & 7.1 & 0 & 0.0 & 5.176 & $0.023 *$ \\
\hline \multicolumn{7}{|c|}{ History of virus B infection } \\
\hline No & 25 & 89.3 & 71 & 100.0 & & \\
\hline Yes & 3 & 10.7 & 0 & 0.0 & 7.845 & $0.005 *$ \\
\hline
\end{tabular}


Table 6. Association Between total Knowledge score and Practices Pre-intervention

\begin{tabular}{|c|c|c|c|c|c|c|}
\hline \multirow{3}{*}{$\begin{array}{l}\text { Variables } \\
\text { Total Knowledge Score }\end{array}$} & \multicolumn{4}{|c|}{ Total Practice Score } & & \\
\hline & \multicolumn{2}{|c|}{ Unsatisfactory $(n=51)$} & \multicolumn{2}{|c|}{ Satisfactory $(n=48)$} & \multicolumn{2}{|c|}{ Chi-Square } \\
\hline & $\mathrm{N}$ & $\%$ & $\mathrm{~N}$ & $\%$ & $\mathrm{X}^{2}$ & $\mathrm{P}$ \\
\hline Poor & 9 & 17.6 & 9 & 18.8 & & \\
\hline Fair & 18 & 35.3 & 6 & 12.5 & & \\
\hline Good & 24 & 47.1 & 33 & 68.8 & 7.337 & $0.025^{*}$ \\
\hline
\end{tabular}

Table 7. Associations Between the Knowledge and Practice post-intervention

\begin{tabular}{|c|c|c|c|c|c|c|}
\hline \multirow{3}{*}{$\begin{array}{l}\text { Variables } \\
\text { Total Knowledge Score }\end{array}$} & \multicolumn{4}{|c|}{ Total Practice Score } & & \\
\hline & \multicolumn{2}{|c|}{ Unsatisfactory $(n=28)$} & \multicolumn{2}{|c|}{ Satisfactory $(n=71)$} & \multicolumn{2}{|c|}{ Chi-Square } \\
\hline & $\mathrm{n}$ & $\%$ & $\mathrm{~N}$ & $\%$ & $X^{2}$ & $\mathrm{P}$ \\
\hline Fair & 4 & 14.3 & 1 & 1.4 & & \\
\hline Good & 24 & 85.7 & 70 & 98.6 & 6.944 & $0.008^{*}$ \\
\hline
\end{tabular}

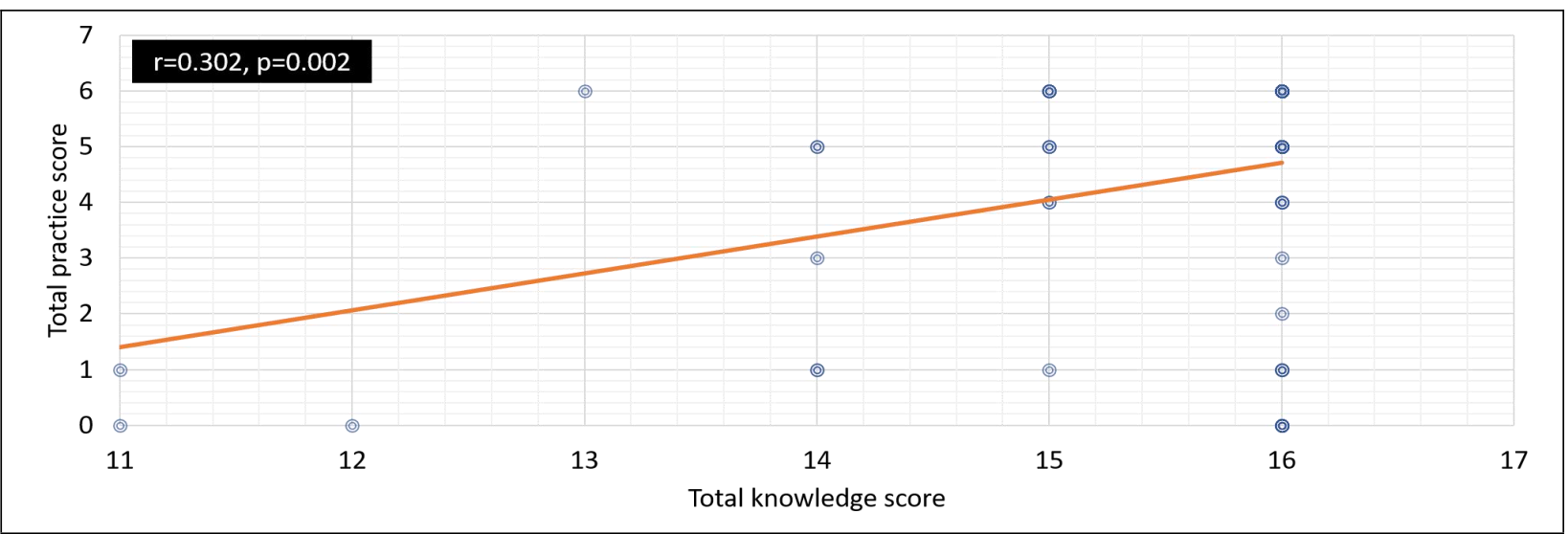

Figure 3. Correlation between Total Knowledge Score and Total Practice Score post-intervention

\section{Discussion:}

Poor waste management may expose health care personnel, waste handlers, clients, $\mathrm{MCHs}$, and the general public to infection, harmful effects, and injury, as well as risk contaminating the environment. It is critical to separate all medical waste products at the point of production, to treat them properly, and to dispose of them securely (WHO, 2014). It is critical to properly manage and dispose of biomedical waste. Regrettably, carelessness and a lack of appropriate understanding and practice regarding biomedical waste disposal contribute to entrenched health and environmental concerns (Ferronato et al., 2019). The present conclusion indicates that waste management is one of the key problems of modern society due to the ever expanding volume and complexity of discarded waste.

The present study's target group was nurses working in Maternal and Child Health Care Centers. This goal was chosen since between $18-64 \%$ of health care facilities are estimated to have inadequate biomedical waste management, owing to a lack of knowledge, limited resources, and ineffective disposal methods (WHO, 2014). Biological waste must be handled and disposed of correctly to safeguard the environment, the public, and employees, particularly nurses and sanitation workers who face occupational hazards from biomedical waste (Elsayed and Rashad, 2014).

Regarding the nurses' age in the present study, the highest percentage ranged between forty one to fifty years with a mean age of $42.2 \pm 9.9$. This finding agrees with that of Elsayed and Rashad (2014) in maternal and child healthcare centers at Kalyubia Governorate, in Egypt, who found that the mean age was 40.62 \pm 9.339 . As well, in the current study, slightly ore than three fifth of nurses have nursing diploma. 
As regards years of experience, more than quarter of nurses had worked between thirty one to forty years and more than half of them have training courses regarding bio-medical waste management, which had a significant effect in increasing the knowledge, and practice levels in pre/post intervention of the nurses. This may be linked to years of experience in an indirect way since it is thought that greater experience results in safer practices. This finding was corroborated by Ozder et al. (2014), who conducted a study on medical waste management training for health care managers and concluded that training programs on waste management in the health sector have a significant effect on increasing the level of knowledge of health care personnel. This finding was consistent with that of Madhavi et al. (2014), in Khammam, who conducted a study on biomedical waste management awareness among interns in a tertiary health care hospital. Their findings indicated that a lack of training in medical waste management influences practices of appropriate waste handling and disposal.

The present research discovered that most nurses lacked enough knowledge about health care waste management prior to the program's introduction. This may be because, despite the existence of laws requiring hospital waste management, appropriate waste management and disposal are not yet being properly executed by healthcare professionals in Egypt. Following the program's deployment, there were substantial improvements in the levels of all knowledge items on the post test. The lower preintervention knowledge levels may be ascribed to a lack of refresher sessions and training throughout employment, the absence of waste management handouts to serve as a nursing guide, and the absence of a waste management orientation program. The present study's findings indicate that most of the sample correctly and completely responded to posttest questions regarding the definition of biomedical waste, its types, sources, those responsible for managing biomedical waste, hazards, waste handling technology, color coding of biomedical waste, and procedures to follow in case of needle prick exposure.

Additionally, there are highly statistically significant associations between socio-demographic characteristics and past medical history (education, profession, years of experience, training about medical waste, vaccination against virus $B$, history of needle injury, history of virus $\mathrm{C}$ infection, and history of virus $\mathrm{B}$ infection), and knowledge post-intervention. These findings confirmed with of Ismail et al. (2016), in Dakshina Kannada, Karnataka, who discovered that knowledge and practice regarding bio-medical waste management were lacking, periodic training and retraining workshops with a special emphasis on proper use of personal protective equipment were necessary prior to implement the program. Similarly, El-Sayed et al. (2014) mentioned that only a minority of nurses correctly answered questions about the definition, types, sources, and health hazards of health care waste, the classification of hazardous waste, the purpose of waste management, which is more vulnerable to waste hazards, and the use of incineration prior to the program's implementation, whereas postimplementation, the score of knowledge was high on these points.

These previous results are congruent with those of Elnour et al. (2015), in Sudan, who reported that most nurses had a reasonable level of knowledge about HCW management prior to the educational intervention program. Following the educational program's execution, the majority demonstrated enough knowledge in the immediate post-test. The present study's findings were also consistent with that of Hussein (2014), of the El-Sharqia study, conducted at Zagazig University Hospital in Egypt, where an educational program on HCW management was implemented. and revealed a significant improvement in nurses' knowledge, with the proportion of nurses with adequate knowledge increasing from $25 \%$ prior to intervention to $78 \%$ following intervention.

Previously, another research showed that just 57.7 percent of respondents were familiar with the four-color codes (Blue/White-Black-Red-Yellow), associated with the bags used to separate bio-medical waste (Mohapatra et al., 2014). This demonstrates the need of refresher training to guarantee long-term sustainability and development. This is consistent with a research performed in India among 100 nurses, which found that $47 \%$ had superior understanding of biomedical waste management (Shivalli \& Sanklapur, 2014). Similarly, research performed in Nigeria found that respondents at different institutions had sufficient understanding about the collection and management of medical waste (Awodele et al., 2016). Additionally, these studies findings were corroborated by those of Rutayisire et al. (2019), in Rwanda, who found that only 49.0 percent of healthcare professionals had enough knowledge regarding waste management prior to the program's implementation.

Regarding previous vaccination against Hepatitis-B virus, more than two thirds of the study participant nurses were vaccinated against hepatitis B. Additionally, a minority of individuals, fewer than a fifth, have a history of repeated needle stick injuries. This may be because of a lack of personal protection 
equipment and a lack of care on the side of handlers. This study is to some extent matched with that reported by the study results conducted by Abiola et al. (2014) in Alausa, Lagos State; which revealed that $74.5 \%$ of these research participants were immunized against the Hepatitis-B virus. In the same line a study done by Sharma (2015), in Agra, revealed that history of needle stick among Class IV waste handlers was almost the same resenting only $19 \%$.

In terms of practice, the current research findings revealed that fewer than three-quarters of nurses properly and fully coded biomedical wastes before to the program's introduction, but substantially rose thereafter. This result matched with that of Mziray (2015), in Finland and Tanzania; where they reported that $\mathrm{HCW}$ are discarded at the moment of usage by the user. The waste is separated according to the color coding of the Muhimbili National Hospital's color-coding system. All employees are instructed on proper HCW handling methods, which include waste segregation, waste packaging, and labeling.

Similarly, the current research results found that participants had the second lowest degree of hand washing practice (following use of personal protector equipment) during the pre-program period. However, there was a highly statistically significant increase in practice level in the post test. This finding was consistent with that of Elnour et al. (2015), who reported that before to the educational intervention program, 42 percent of students, in Sudan, had excellent, 55 percent had fair, and 3 percent had low levels of practice. Following the intervention program's deployment, an instant post-test revealed that most participants had improved their practice. This finding is consistent with that of Ebrahim (2014), who evaluated the quality of treatment at Cairo University Hospitals in Egypt, and found that wearing gloves and hand-washing are two areas where nurses require more training. These results are also consistent with those of an earlier research conducted in Al-Mansoura, Egypt, by El-Sayed et al. (2014), whose results revealed that pre-intervention nurses had poor practice mean scores for segregation and collection of $\mathrm{HCW}$. However, these previous findings contradict with those of Rutayisire et al. (2019) in Rwanda, who found that $133(66.5 \%)$ had inadequate procedures for managing bio-medical waste.

The current research findings revealed that more than three quarters of nurses identify and separate infectious and non-infectious waste, as well as perform waste segregation at the source of waste production. This result was supported by Nagaraju et al. (2017), who stated that segregation is the nurse's responsibility when introducing health care to clients; it must occur at the point of origin and immediately following care, as practical segregation at the source is the primary factor that enables health care facilities to function. Additionally, Mathur et al. (2021) in a very recent study define segregation as separating waste by type and suggested that hazardous waste must be handled carefully to avoid illness or injury. As a result, separating it at the point of generation may significantly decrease the quantity of waste that requires special treatment. However, this research findings contradicts with that of Rutayisire et al. (2019) study in Rwanda, where they mentioned that most healthcare staff $133(66.5 \%)$ had inadequate procedures for bio-medical waste management. Their finding is less than that of research conducted in Pakistan, in which 94.3 percent of study participants reported having sufficient practice (Ajmal, 2017). This discrepancy may be explained by the regulatory body's lack of enforcement or oversight in health institutions.

The results of this research established a statistically significant relationship between nurses' knowledge and practice ratings. This was confirmed by Hussein (2014), who discovered a strong positive correlation between nurses' knowledge and practices throughout the training program. As well, Sarma et al. (2014) reported that they found that the nurses with good knowledge, their practice percentage is also very high.

The current research discovered highly statistically significant correlations between overall knowledge, practices, and years of experience among the nurses examined throughout the program. This result was supported by El-Azab (2015), who corroborated this finding by conducting a study at two hospitals, Benha University Hospital and Benha Teaching Hospital, on nurses' and workers' awareness and commitment to the hospital waste management system. El-Azab reported that a highly statistically significant association between nurses' awareness of waste management and years of experience. This shows how increased knowledge may result in more appropriate practice. It's enthralling to conceive of a knowledge threshold at which theoretical knowledge becomes practical.

\section{Conclusion}

Based on the current study findings, it was concluded that, the educational program effectively improved nurses' knowledge, while the practice in relation to management of health care waste is still 
inadequate. There was a highly statistically significant positive linear correlation between the nurses' knowledge and reported practices regarding management of health care waste before and after the implementation of the educational program $(\mathrm{p}<0.01)$.

\section{Recommendations}

Considering this research results, the following suggestions are made:

- Pre-employment, health educational programs should be provided for Egyptian nurses on biomedical waste management with orientation to organization and should be checked regularly.

- Periodic in-service education sessions for all nurses to address knowledge and practice gaps about safe biomedical waste disposal in $\mathrm{MCH}$ facilities.

- Proper waste segregation at the source must be implemented and color-coding must work hand-inhand with segregation.

- Adequate supplies and equipment should be available in $\mathrm{MCH}$ centers to take care of waste properly.

- All nurses should be vaccinated against virus B.

\section{Acknowledgement}

Great thanks to all nurses who participated in this study.

\section{Declaration of Conflicting of Interests}

The authors declared no potential conflicts of interests concerning the research, authorship, and/or publication of this article.

\section{Funding}

The authors received no financial support for the research, authorship, and/or publication of this article.

\section{References}

Abiola, A.O., Omoyeni, O.E., \& Akodu, B.A. (2014): Knowledge, attitude and practice of hepatitis $B$ vaccination among health workers at the Lagos State accident and emergency center, Toll-Gate, Alausa, Lagos State. West Afr J Med; 32(4):257-262.

Ajmal, M. (2017): Knowledge and practices of biomedical waste management among paramedic staff of Jinnah hospital, Lahore. Biologia.;63(1):59-66.
Awodele, O., Adewoye, A.A., \& Oparah, A. C. (2016): Assessment of medical waste management in seven hospitals in Lagos, Nigeria. BMC Public Health, 16(1): 269.

Debere, M.K., Gelaye, K.A., Alamdo, A.G., \& Trifa, Z.M. (2014): Assessment of the health care waste generation rates and its management system in hospitals of Addis Ababa, Ethiopia, 2011. BMC Public Health., 13: 28-10.1186/1471-2458-13-28. doi:10.1186/1471-2458-13-28

Ebrahim, S.A. (2014): Environmental impacts to the problem of waste disposal by incineration, Journal of Assiute Environmental Studies (36).

El-Azab, NA (2015): Awareness and commitment of nurses and workers toward hospital waste management system, Master thesis submitted to Faculty of Nursing, Benha University, p. 96

Elnour, A.M., Moussa, M.M.R. El-Borgy M.D., Fadelella, N.N.E., \& Mahmoud, A.H. (2015): Impacts of health education on knowledge and practice of hospital staff with regard to healthcare waste management at White Nile State main hospitals, Sudan. Int J Health Sci; 9(3):315-31.

Elsayed, H.A., and Rashad, R.M. (2014): Intervention program about Health Care Waste Management for Nurses working in Maternal and Child Health Care Centers At kalyubia Governorate. PP: 1:24.

El-Sayed, I. Zakaria, A. and Gheith, N. (2014): Intervention program for nurses about health care waste management, Mansoura University Hospital. Research Journal of Medicine and Medical Sciences; 7(1): 25-37.

Ferronato, N., Rada, E.C., Gorritty Portillo M.A., Cioca, L.I., Ragazzi, M., \& Torretta, V. (2019): Introduction of the circular economy within developing regions: A comparative analysis of advantages and opportunities for waste valorization. J Environ Manage. Jan 15;230:366-378. doi: 10.1016/j.j envm an .2018.09.095. Epub 2018 Oct 4. PMID: 30293021.

Hakim, S.A., Mohsen, A., and Bakr, I. (2017): Knowledge, attitudes and practices of healthcare personnel towards waste disposal management at Ain Shams University Hospitals, Cairo. EMHJ; 20(5): 347:354.

Haque, M., Sartelli, M., McKimm, J., \& Abu Bakar, M. (2018): Health care-associated infections - an overview . Infecti on and drug resistance, 11, 23212333. https://doi.org/10.2147/IDR.S177247

Hussein, F.M. (2014): Implementation: A Developed nursing care standards for hemodialysis patients in Zagazig University Hospital. Ph. Thesis. Faculty of Nursing, Zagazig University, Egypt, 99: 53-55.

Ismail, I.M., Annarao, G., Kulkarni, S.V., Kamble, S.A., Borker, H.R., and Amruth, M. (2016): Knowledge, attitude and practice about bio-medical 
waste management among personnel of a tertiary health care institute in Dakshina Kannada, Karnataka. Al Ameen J Med Sci; 6(4):376-380.

Madhavi, K., Reddy, B., and Ravikumar, B. (2014): Awareness regarding biomedical waste management among interns in a tertiary health care hospital, Khammam. Journal of Evolution of Medical and Dental Sciences; 2(29): 5360-5365.

Maroufi, M., Javadi, M., Yaghoubi, M., \& Karimi, S. (2014): Function of nurses and other staff to minimize hospital waste in selected hospitals in Isfahan. Iranian Journal of Nursing and Midwifery Research; 17(6):445-50.

Mathur, P., Patan, S., \& Shobhawat, S. (2021): Need of biomedical waste management system in hospitals - An Emerging issue - A Review. Current World Environment; 7(1): 117-124.

Mohapatra, A., Gupta, M. Shivalli, CP., and Mohapatra, S.C. (2014). Bio-medical waste management practices of doctors: an online snapshot," National Journal of Community Medicine; 2 (3): 227231.

Mostafa, M., Shazly, M., \& Sherief, W. (2014): Development of a waste management protocol based on assessment of knowledge and practice of health care personnel in surgical departments. Waste Management; 2(9): 430-439.

Mziray, R. (2015): Comparative study of hospital waste management and separation at site, case study of Tampere University Hospital In Tampere, Finland And Muhimbili National Hospital in Dar-Es-Salam, Tanzania Ajmal, S.

Nagaraju, B., Padmavathi, G.V., \& Puranik, D.S. (2017): A study to assess the knowledge and practice on bio-medical waste management among the health care providers working in PHCs of Bagepalli Taluk with the view to prepare informational booklet". International Journals of Medical Biomed and Research; 2(1): 28-35.

Ozder, A., Teker, B., Eker, H., Altındis, S., Merve, K., and Karabay, O. (2014): Medical waste management training for healthcare managers- a necessity? Journal of Environmental Health Science and Engineering; 8(13): 35-39.

Padmanabhan, K.K., \& Barik, D. (2019): Health Hazards of Medical Waste and its Disposal. Energy from Toxic Organic Waste for Heat and Power Generation, 99-118. https://doi.org/10.1016/B978-008-102528-4.00008-0

Rutayisire, E., Nsabimana, J.A., \& Habtu, M. (2019): Knowledge and Practice for Bio-Medical Waste Management among Healthcare Personnel at Kabgayi District Hospital, Rwanda. Journal of Public Health International; 1(4) 34:44.

Sağlık, Ç., Tıbbi, D., \& Değerlendirilmes, I. (2014): Waste management, University of A cibadem health $\backslash$ sciences. [Retrieved from http://www.sciencedirect.com/science/article "Edi torialBoard/Aims \&Scopes. Acrbadem Universities Sağlık Bilimleri Dergisi

Sarma, R., Nagarajan, S., and Facilities, S. (2014): Waste attitudes and actions. Available http://ww w.asianhhm.com/f acilities_operation s/attitudes_actions.htm.

Sharma, S. (2015): Awareness about biomedical waste management among health care personnel of some important medical centers in Agra. International Journal of Environmental Science and Development, 1(3): 251-255.

Shivalli, S., and Sanklapur, V. (2014): Healthcare waste management: qualitative and quantitative appraisal of nurses in a tertiary care hospital of India. Scientific World Journal. 935101.

World Health Organization (WHO). (2014): Health care waste management Available on the http://www.who.int/mediac

entrefactsheets/Fs281/en/index.html. Retrieved at 3. Oct, 2021, 8:45pm

World Health Organization (WHO). (2014): Wastes from healthcare activities. Factsheet N.(253), November. Available from: http://www.who.int/mediacentre/factsheets/fs253/en.

World Health Organization WHO, (2014): Water Sanitation Health: Safe management of wastes from healthcare activities. available at http://www.who.int/water_sanitationhealth/medic alwaste/wastemanag/en 